\title{
Analisis Pemasangan Filter Pasif untuk Menanggulangi Distorsi Harmonisa Terhadap Beban non Linier di PT.Wisesa Group
}

\author{
I Wayan Wahyu Adi Merta ${ }^{1}$, I Gusti Ngurah Janardana ${ }^{2}$, I Wayan Arta Wijaya ${ }^{3}$
}

\begin{abstract}
PT.Wisesa Group is located at No. 199 Jalan Hayam Wuruk Denpasar, PT.Wisesa Group possessed two buildings and one warehouse building where terpasan power of 197 KVA. Almost all electrical equipment is currently based micro-electronics. Equipment of this type is a type of non-linear load. Installation of a passive filter which aims to reduce harmonics that exceeds the standard IEEE 519-1992. In this study conducted a simulation using passive filter type c using software etap, The type of non-linear load, calculate the active power (P) and calculate the load current (IL), simulation of the system before and after the use of passive filters. The analysis showed a passive filter installation cause voltage and current THD content complies with the standards specified IEEE 5191992 is $\leq \mathbf{5 \%}$. Power harmonic distortion at each SDP decreased. C-type passive filter placement is best to lower THD and power distortion, namely the SDP 5 because it can reduce current THD of the total of $31.32 \%$ to $3.48 \%$.
\end{abstract}

Intisari- PT.Wisesa Group terletak di jalan Hayam Wuruk No 199 Denpasar, PT.Wisesa Group mempunya 2 gedung dan 1 bangunan gudang dimana daya yang terpasan sebesar 197 KVA. Hampir semua peralatan listrik yang ada saat ini berbasiskan mikro elektronik. Peralatan jenis ini merupakan jenis beban non linier yang dapat menghasilkan harmonisa tinggi dan dapat mengganggu sistem kelistrikan. Pemasangan filter pasif yang bertujuan untuk meredam harmonisa yang melebihi standar IEEE 519-1992. Dalam penelitian ini dilakukan simulasi penggunaan filter pasif type $c$ menggunakan sofware etap, jenis beban non linear, perhitungan daya aktif (P) dan arus beban (IL), simulasi pada sistem sebelum dan sesudah penggunaan filter pasif. Hasil analisis menunjukkan pemasangan filter pasif menyebabkan kandungan THD arus dan tegangan telah sesuai dengan standar IEEE 519-1992 yang ditentukan yaitu $\leq \mathbf{5 \%}$. Daya distorsi harmonisa pada setiap SDP mengalami penurunan. Penempatan filter pasif type c yang terbaik untuk menurunkan THD dan distorsi daya yaitu pada SDP 5 karena dapat menurunkan THD arus terbesar yaitu 31,32 \% menjadi 3,48 \%.

Kata kunci- Harmonisa, Distorsi Harmonisa, Beban Non Linier, Filter Pasif Type C

\footnotetext{
${ }^{1}$ Mahasiswa, Jurusan Teknik Elektro Fakultas Teknik Universitas Udayana,Jalan Kampus Bukit jimbaran, Bali 80361 INDONESIA (Hp: 082247559892; e-mail: wahyuadi_merta@yahoo.com )

${ }^{2,3}$ Dosen Jurusan Teknik Elektro Fakultas Teknik Universitas Udayana, Jalan Kampus Bukit Jimbaran 80361 INDONESIA (telp: 0361-703315; fax: 0361-4321; e-mail:

janardan@unud.ac.id ,3artawijaya@ee.unud.ac.id )
}

Peningkatan pengoprasian beban-beban non linier signifikan dengan timbulnya distorsi pada sistem daya. Pada sistem tiga phasa elemen elemen non linier akan menimbulkan harmonisa pada rangkaian dan mengakibatkan beban menjadi tak seimbang yang di sebabkan oleh perbedaan nilai phasa $\mathrm{R}, \mathrm{S}, \mathrm{T}[1]$. Peralatan elektronik yang digunakan untuk menunjang fasilitas seperti AC (Air Conditioner), TV, lampu daylight PLC, alat-alat music, pralatan medis dan lain sebagainya yang dikategorikan sebagai beban nonlinier. Hasil pengukuran $\mathrm{THD}_{\mathrm{I}}$ didapatkan sebesar $26,8 \%$ yang berarti melebihi nilai standar IEEE 519-1992 yang telah ditentukan yaitu sebesar $\leq 15,0 \%$. Pengukuran $\mathrm{THD}_{\mathrm{V}}$ sebesar $2,3 \%$, dimana kondisi tersebut masih memenuhi standar maksimum $\mathrm{THD}_{\mathrm{V}}$ sebesar $\leq 15 \%$, menurut IEEE Standard 519-1992, untuk mengetahui standar batas maksimum $\mathrm{THD}_{\mathrm{i}}$ pada utility, maka harus diketahui terlebih dahulu rasio hubung singkat $\left(\mathrm{SC}_{\text {ratio }}\right)$. Filter harmonisa merupakan suatu teknologi elektronika daya untuk menghasilkan komponen arus spesifik yang bertujuan untuk meredam arus harmonisa yang dihasilkan oleh beban non linier. Jenis filter yang digunakan dalam penelitian ini merupakan filter pasif type c, dimana filter pasif type c tidak ada rugi-rugi daya fundamental, di reting VAR dan juga tepat untuk memfilter harmonisa rendah maupun tinggi[1], [2].

\section{HARMONISA}

Berdasarkan Standart IEC (International Electrotechnical Commission) 1000.4-11, harmonisa bisa digolongkan kedalam distorsi bentuk-bentuk gelombang[3], karena adanya perubahan bentuk gelombang dari gelombang dasarnya. Harmonisa adalah tegangan dan arus sinusoidal yang mempunyai kelipatan frekuensi sistem tenaga listrik sebagaimana yang dirancang untuk beroperasi di frekuensi $50 \mathrm{~Hz}$ atau $60 \mathrm{~Hz}$. Ada empat sebab dasar yang menyebabkan terjadinya harmonisa, yaitu[4]:

1. Sumber arus dan tegangan non sinusoidal dan elemenelemen rangkaian (resistor, induktor, dan kapasitor) adalah linier (independent),

2. Sumber arus dan tegangan sinusoidal, sedangkan elemen-elemen rangkaian mengandung elemen nonlinier,

3. Sumber arus dan tegangan non sinusoidal, sedangkan elemen-elemen rangkaian non-linier,

4. Sumber arus dan tegangan yang berupa sumber DC, sedangkan rangkaiannya mengandung elemen yang berubah secara periodik.

Ada dua criteria harmonisa yaitu distorsi harmonisa arus $\left(\mathrm{THD}_{\mathrm{I}}\right)$ dan harmonisa tegangan $\left(\mathrm{THD}_{\mathrm{V}}\right)$.Harmonisa juga 
memiliki batasan yang akan ditentukan dengan perbandingan arus hubung singkat pada PCC (Point of Common Coupling), dan $\mathrm{I}_{\mathrm{L}}$ dapat disebut arus beban fundamental. Batas harmonisa tegangan sendiri ditentukan dari besarnya tegangan sistem yang terpasang.Standar harmonisa yang diizinkan untuk arus dan tegangan berdasarkan IEEE 519-1992 sesuai dengan Tabel I dan Tabel II[4],[6].

Menurut IEEE Standard 519-1992, untuk mengetahui standar batas maksimum $\mathrm{THD}_{\mathrm{I}}$ pada utility, maka harus diketahui terlebih dahulu rasio hubung singkat (short-circuit ratio) agar dapat menghitung batas maksimum $\mathrm{THD}_{\mathrm{I}}$.

TABEL I

STANDAR HARMONISA UNTUK ARUS DAN TEGANGAN BERDASARKAN IEEE 519-1992 [4]

\begin{tabular}{|c|c|c|c|c|c|c|}
\hline \multicolumn{7}{|c|}{ Maximum Harmonik current Distortion $\mathbf{I}_{\mathbf{n}} \% \mathbf{I}_{\mathbf{L}}$} \\
\hline \multicolumn{7}{|c|}{ Individual harmonic Order (Odd Harmonics) } \\
\hline $\mathrm{I}_{\mathrm{SC}} / \mathrm{I}_{\mathrm{L}}$ & $<11$ & $11=<\mathrm{h}<17$ & $17=<\mathrm{h}<23$ & $23=<\mathrm{h}<35$ & $35=<\mathrm{h}$ & THD\% \\
\hline$<20$ & 4 & 2 & 1.5 & 0.6 & 0.3 & 5 \\
\hline $\begin{array}{c}20- \\
50\end{array}$ & 7 & 3.5 & 2.5 & 1 & 0.5 & 8 \\
\hline $\begin{array}{c}50- \\
100\end{array}$ & 10 & 4.5 & 4 & 1.5 & 0.7 & 12 \\
\hline $\begin{array}{c}100- \\
1000\end{array}$ & 12 & 5.5 & 5 & 2 & 1 & 15 \\
\hline$>1000$ & 15 & 7 & 6 & 2.5 & 1.4 & 20 \\
\hline
\end{tabular}

$\mathrm{SC}_{\text {ratio }}$ akan dapat dicari dengan rumus berikut :

$S C_{\text {ratio }}=\frac{I_{S C}}{I_{L}}$

$\mathrm{I}_{\mathrm{sc}}$ (Arus hubung singkat)akan dapat dicari dengan rumus berikut :

$\mathrm{I} s \mathrm{c}=\frac{\mathrm{kVA} \times 100}{\sqrt{3} \times \mathrm{kV} \times \mathrm{Z}(\%)}$

$\mathrm{I}_{\mathrm{L}}$ (Arus beban maksimum)akan dapat dicari dengan rumus berikut :

$I_{L}=\frac{K W}{P F \cdot \sqrt{3} \cdot K V}$

Keterangan:

$I_{S C}$ : adalah Arus hubung singkat maksimum pada PCC.

$I_{L} \quad$ adalah Arus beban maksimum.

$k W$ :adalahTotal daya aktif[4],[7].
TABEL II

DISTORTION LIMITS VOLTAGE [1]

\begin{tabular}{|c|c|c|}
\hline $\begin{array}{c}\text { Voltage at } \\
\text { PCC }\end{array}$ & $\begin{array}{c}\text { Individual Voltage } \\
\text { Distortion }(\%)\end{array}$ & $\begin{array}{c}\text { Total Harmonic } \\
\text { Distortion THD }(\%)\end{array}$ \\
\hline $69 \mathrm{kV}$ & 3,0 & 5,0 \\
\hline $\begin{array}{c}69 \mathrm{kV}-161 \\
\mathrm{kV}\end{array}$ & 1,5 & 2,5 \\
\hline $161 \mathrm{kV}$ & 1,0 & 1,5 \\
\hline
\end{tabular}

A. BebanNon-linier

Harmonisa akan disebabkan dengan adanya arus beban non-linier yang impedansinya tidak konstan dalam setiap periode akan tegangan masukannya dengan arus yang dihasilkan tidak bisa berbanding lurus dengan tegangan yang diperoleh. Sehingga nanti beban-beban non-linier tidak mematuhi dan mengikuti Hukum Ohm yang menetapkan arus berbanding lurus dengan tegangan yang di hasilkan[4]. Gelombang tegangan dan arus dan yang dihasilkan oleh beban non-linier maka tidak sama dan menjadi cacat (distorsi) sesuai dengan Gambar 1.

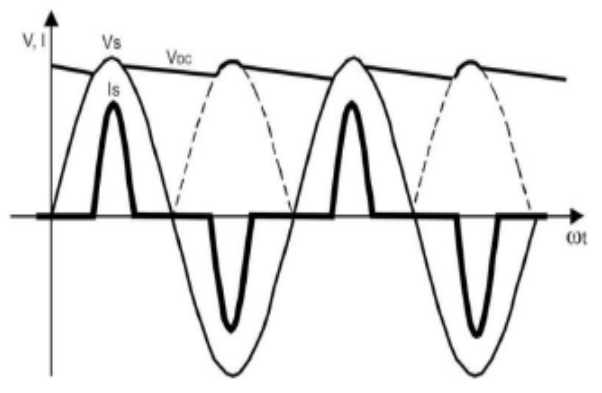

Gambar 1. Arus gelombang dan beban non-linier [5]

\section{B. Pemanfaatan Filter Harmonisa}

Filter harmonisa biasanya dipasang pada transformator distribusi atau panel kontrol utama. Dengan penambahan filter harmonisa pada suatu sistem tenaga listrik yang mengandung suber-sumber harmonisa, maka penyebaran arus harmonisa ke seluruh jaringan dapat di tekan sekecil mungkin. Secara umum filter harmonisa ada 3 tipe, yaitu filter aktif, filter pasif dan filter hybrid[5].

\section{Filter Harmonisa Pasif}

Filter pasif terdiri dari induktor, kapasitor, resistor (R,L,C) dan unsur-unsur tahanan untuk meredam marmonisa.Type $\mathrm{C}$ filter tepat untuk digunakan karena tidak ada rugi-rugi daya fundamental, derating VAR dan juga tepat untuk memfilter pada harmonisa yang tinggi. Type $\mathrm{C}$ filter mempunyai dua kapasitor dengan sebuah kapasitor dihubung secara seri dengan resistor dan induktor seperti Gambar 2[5]. 


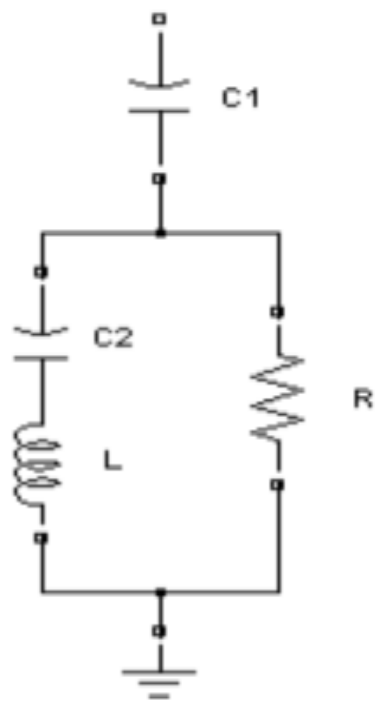

Gambar 2. Rangkaian Type-C Filter

III. METODELOGI PENELITIAN

Penelitian dilakukan di PT. Wisesa Group. Alur analisis langkah penelitian sesuai dengan Gambar 3.

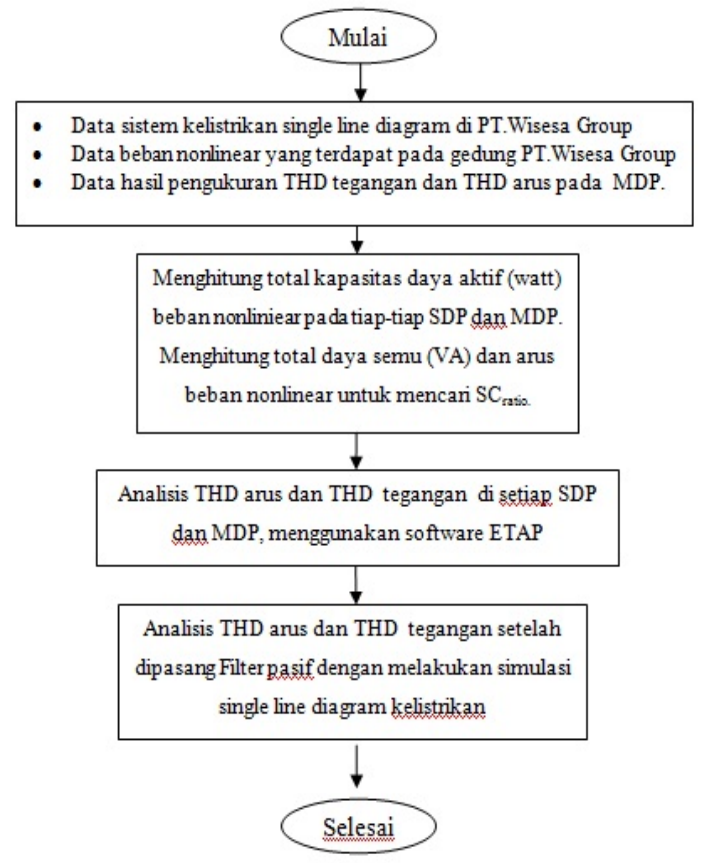

Gambar 3. Langkah penelitian

Tahapan dari Gambar 3 proses analisis pemasangan filter pasif untuk menanggulangi distorsi harmonisa terhadap beban non linier dapat dijelaskan sebagai berikut :

1. Pengumpulan Data sistem kelistrikan single line diagram di PT.Wisesa Group.

2. Pengumpulan data jumlah beban nonlinear yang terdapat pada setiap gedung dan data hasil pengukuran THD arus dan THD tegangan pada setiap panel.
3. Menghitung total kapasitas daya aktif (watt) beban non liniear pada tiap-tiap panel untuk mengetahui standar batas THD ( $\left.\mathrm{SC}_{\text {ratio }}\right)$.

4. Menghitung arus hubung singkat (Isc).

5. Analisis THD arus dan THD tegangan dengan melakukan simulasi menggunakan software ETAP.

6. Membuat model simulasi menggunakan software ETAP.

7. Analisis pemasangan filter pasif untuk meredam distorsi dengan mengunakan software ETAP.

8. Analisis hasil simulasi berdasarkan IEEE standard 5191992.

\section{HASIL DAN PEMBAHASAN}

\section{A. Sistem Kelistrikan}

Sistem kelistrikan di PT.Wisesa Group sesuai dengan gambar single line dibawah.

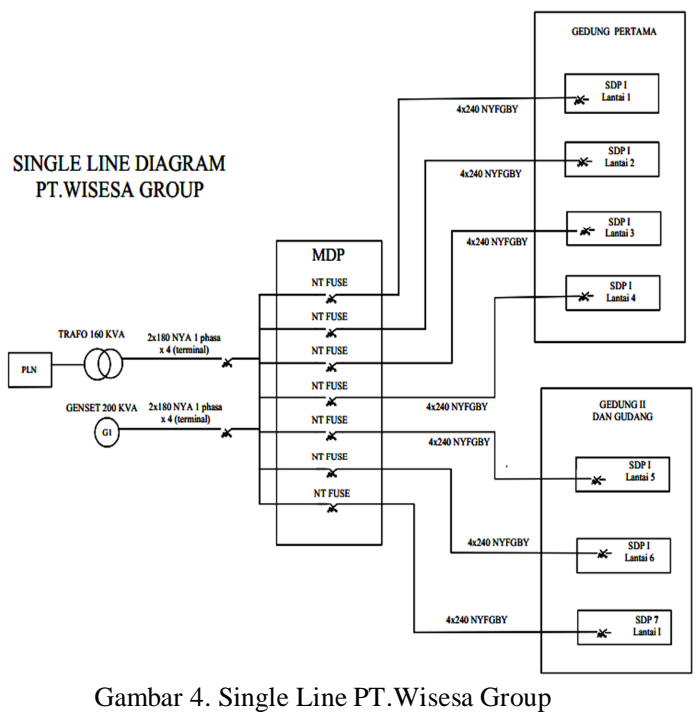

Sistem distribusi primer di Gedung PT.Wisesa Group terbagi menjadi satu buah MDP (Main Distribution Panel), pada MDP terdapat tujuh buah SDP (Sub Distribution Panel). Pada sistem distribusi di Gedung PT.Wisesa Group terdapat satu buah transformator tenaga yang menyuplai beban-beban menuju MDP. Dari suplai PLN dengan kapasitas 197 KVA dan Genset dengan kapasitas 200 KVA yang kemudian di distribusikan ke MDP. Dari MDP, daya listrik kemudian disalurkan ke SDP yang selanjutnya disalurkan ke beban atau pemakai.

\section{B. Pengelompokan Data Beban Non Linier pada Setiap Gedung}

Beban-beban non linier yang terdapat di tiap ruang dikelompokkan terlebih dahulu berdasarkan ruang di setiap gedung. Dari data-data pembebanan listrik pada setiap ruang di Gedung PT.Wisesa Group, diketahui bahwa terdapat 1 buah MDP yang menyuplai daya listrik ke SDP 1, SDP 2, SDP 3, SDP 4, SDP 5, SDP 6, SDP 7. 
C. Data Hasil Pengukuran THD tegangan dan THD arus

Di bawah dapat dilihat bahwa hampir semua SDP, THD $_{\mathrm{i}}$

Hasil pengukuran tidak sesuai dengan standar yang diperboleh yaitu $15 \%$ seperti pada tabel III di bawah. Sedangkan THDv masih memenuhi standard yaitu di bawah $5 \%$.

TABEL III

HASIL PENGUKURAN THDI DAN THDV DI PT.WISESA GROUP

\begin{tabular}{|c|c|c|c|c|}
\hline $\begin{array}{l}\text { Tem } \\
\text { pat }\end{array}$ & Phasa & $\begin{array}{l}\text { Pengukuran THD } \mathrm{TH}_{\mathrm{I}} \\
\text { (\%) di PT.Wisesa } \\
\text { Group }\end{array}$ & $\begin{array}{c}\text { IEEE } \\
\text { Standar } 519 \\
-1992 \\
\text { THD }(\%)\end{array}$ & KET \\
\hline \multirow{3}{*}{$\begin{array}{c}\text { SDP } \\
1\end{array}$} & $\mathrm{R}$ & 10,1 & 5.0 & Tidak Standar \\
\hline & $\mathrm{S}$ & 9,4 & 5.0 & Tidak Standar \\
\hline & $\mathrm{T}$ & 11,5 & 5.0 & Tidak Standar \\
\hline \multirow{3}{*}{$\begin{array}{c}\text { SDP } \\
2\end{array}$} & $\mathrm{R}$ & 21,4 & 5.0 & Tidak Standar \\
\hline & $S$ & 20,9 & 5.0 & Tidak Standar \\
\hline & $\mathrm{T}$ & 18,4 & 5.0 & Tidak Standar \\
\hline \multirow{3}{*}{$\begin{array}{c}\text { SDP } \\
3\end{array}$} & $\mathrm{R}$ & 17,2 & 5.0 & Tidak Standar \\
\hline & $\mathrm{S}$ & 10,7 & 5.0 & Tidak Standar \\
\hline & $\mathrm{T}$ & 14,9 & 5.0 & Tidak Standar \\
\hline \multirow{3}{*}{$\begin{array}{c}\text { SDP } \\
4\end{array}$} & $\mathrm{R}$ & 16,5 & 5.0 & Tidak Standar \\
\hline & $\mathrm{S}$ & 14,9 & 5.0 & Tidak Standar \\
\hline & $T$ & 16,6 & 5.0 & Tidak Standar \\
\hline \multirow{3}{*}{$\begin{array}{c}\text { SDP } \\
5\end{array}$} & $\mathrm{R}$ & 26,8 & 5.0 & Tidak Standar \\
\hline & $S$ & 28,3 & 5.0 & Tidak Standar \\
\hline & $\mathrm{T}$ & 25,5 & 5.0 & Tidak Standar \\
\hline \multirow{3}{*}{$\begin{array}{c}\text { SDP } \\
6\end{array}$} & $\mathrm{R}$ & 22,3 & 5.0 & Tidak Standar \\
\hline & $S$ & 29,9 & 5.0 & Tidak Standar \\
\hline & $T$ & 27,1 & 5.0 & Tidak Standar \\
\hline \multirow{3}{*}{$\begin{array}{c}\text { SDP } \\
7\end{array}$} & $\mathrm{R}$ & 11,4 & 5.0 & Tidak Standar \\
\hline & $S$ & 14,8 & 5.0 & Tidak Standar \\
\hline & $\mathrm{T}$ & 12,4 & 5.0 & Tidak Standar \\
\hline
\end{tabular}

D. Menghitung total daya aktif, daya semu dan beban non linier pada tiap-tiap SDP

Daya aktif yang terpasang pada SDP 1 dimana phasa R: 7985 watt, S: 7523 watt, dan T: 7745 watt. Dari hasil pengukuran yang dilakukan pada tiap panel, dengan mengunakan alat ukur didapatkan besar faktor daya pada sistem kelistrikan di Gedung PT.Wisesa Group yaitu 0,85.

$$
\begin{aligned}
\text { Daya Semu }(\mathrm{VA})=\frac{\text { Daya Aktif }(\text { Watt })}{\operatorname{Cos} \theta} \\
=\frac{7.985}{0,85}=9.394 \mathrm{VA}
\end{aligned}
$$

Arus beban nonlinier $\left(\mathrm{I}_{\mathrm{NL}}\right)=\frac{\operatorname{Daya} \operatorname{Aktif}(\mathrm{W})}{\sqrt{3} \cdot \mathrm{V}_{\text {sistem }}(\mathrm{V}) \cdot \mathrm{pf}}$ diketahui $\mathrm{pf}=0,85$

$$
=\frac{7.985}{323,5}=24,64 \mathrm{~A}
$$

I Wayan Wahyu Adi Merta: Analisis Pemasangan Filter Pasif...
Kemudian dengan menggunakan metode yang sama akan diperoleh nilai daya semu dan arus beban-beban non linear pada tiap-tiap SDP lainnya dapat di lihat di tabel IV di bawah

TABEL IV

\begin{tabular}{|c|c|c|c|c|}
\hline \multicolumn{5}{|c|}{ TIAP SDP } \\
\hline \multirow[t]{2}{*}{ Tempat } & \multirow[t]{2}{*}{ Phasa } & $\begin{array}{c}\text { Daya Aktif } \\
\text { (P) }\end{array}$ & $\begin{array}{c}\text { Daya Semu } \\
\text { (S) }\end{array}$ & $\begin{array}{c}\text { Arus Beban } \\
\text { Non Linier } \\
\left(\mathrm{I}_{\mathrm{NL}}\right)\end{array}$ \\
\hline & & Watt & VA & Ampere \\
\hline \multirow{3}{*}{ SDP 1} & $\mathrm{R}$ & 7.985 & 9.394 & 24,64 \\
\hline & $\mathrm{S}$ & 7.523 & 8.850 & 23,25 \\
\hline & $\mathrm{T}$ & 7.745 & 9.111 & 23,94 \\
\hline \multirow{3}{*}{ SDP 2} & $\mathrm{R}$ & 10.133 & 11.921 & 31,32 \\
\hline & $S$ & 9.899 & 11,645 & 30,59 \\
\hline & $\mathrm{T}$ & 10.412 & 12.249 & 32,18 \\
\hline \multirow{3}{*}{ SDP 3} & $\mathrm{R}$ & 4.442 & 5.225 & 13,73 \\
\hline & $\mathrm{S}$ & 3.779 & 4.445 & 11,68 \\
\hline & $\mathrm{T}$ & 3.887 & 4.572 & 12,01 \\
\hline \multirow{3}{*}{ SDP 4} & $\mathrm{R}$ & 8.441 & 9.930 & 26.09 \\
\hline & $\mathrm{S}$ & 9.213 & 10.838 & 28,47 \\
\hline & $\mathrm{T}$ & 8.141 & 9.577 & 25.16 \\
\hline \multirow{3}{*}{ SDP 5} & $\mathrm{R}$ & 9.342 & 10.990 & 28.87 \\
\hline & $\mathrm{S}$ & 10.112 & 11.896 & 31,25 \\
\hline & $\mathrm{T}$ & 9.326 & 10.971 & 28,82 \\
\hline \multirow{3}{*}{ SDP 6} & $\mathrm{R}$ & 6.667 & 7.843 & 20.60 \\
\hline & $\mathrm{S}$ & 6.768 & 7.962 & 20,92 \\
\hline & $\mathrm{T}$ & 6.845 & 8.052 & 21,17 \\
\hline \multirow{3}{*}{ SDP 7} & $\mathrm{R}$ & 2.322 & 2.731 & 7.17 \\
\hline & $\mathrm{S}$ & 2.431 & 2,860 & 8,84 \\
\hline & $\mathrm{T}$ & 2,112 & 2.490 & 6.52 \\
\hline
\end{tabular}

DAYA AKTIF, DAYA SEMU DAN BEBAN NON LINIER PADA TIAPTIAP SDP

E. Simulasi Analisis $T H D_{I}$ dan $T H D_{V}$

Berikut merupakan hasil running simulasi $\mathrm{THD}_{\mathrm{I}}$ dan $\mathrm{THD}_{\mathrm{V}}$ pada sistem jaringan PT.Wisesa group menggunakan simulasi software etap.

1. Analisis $T H D_{I}$ di PT. Wisesa Group

Hasil perhitungan mengenai short-circuit ratio di PT.Wisesa Group maka sesuai dengan IEEE standar 519-1992. Di tabel $\mathrm{V}$ di bawah ini hasil running simulasi kandungan THD I pada masing-masing SDP di PT.Wisesa Group.

TABEL V

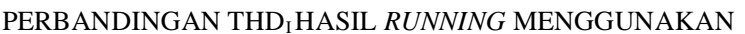
SIMULASI DENGAN STANDAR YANG DI TETAPKAN IEEE 519-1992

\begin{tabular}{|c|c|c|c|}
\hline Tempat & $\begin{array}{c}\text { Hasil running } \\
\text { THD }(\%) \\
\text { PT.Wisesa Group }\end{array}$ & $\begin{array}{c}\text { IEEE Standar 519- } \\
1992 \\
\text { THD Imax }_{\text {Im }}(\%)\end{array}$ & KET \\
\hline Gedung I & 5.0 & Tidak Standar \\
\hline SDP 1 & 8,98 & 5.0 & Tidak Standar \\
\hline SDP 2 & 8,98 & 5.0 & Tidak Standar \\
\hline SDP 3 & 8,97 & 5.0 & Tidak Standar \\
\hline SDP 4 & 8,97 & 5.0 & Tidak Standar \\
\hline Gedung II & 34,80 & 5.0 & Tidak Standar \\
\hline SDP 5 & 25,67 & 5.0 & Tidak Standar \\
\hline SDP 6 & 12,04 & \multicolumn{5}{|c|}{} \\
\hline Gudang & SDP 7 &
\end{tabular}

p-ISSN:1693 - 2951; e-ISSN: 2503-2372 
Tabel $\mathrm{V}$ di atas terlihat nilai $\mathrm{THD}_{\text {I }}$ pada SDP 1 dengan nilai 8,98 \%, dan SDP 2 dengan nilai 8,98 \%,SDP 3 dengan nilai $8,97 \%$, SDP 4 dengan nilai $8,97 \%$, dan nilai persentase $\mathrm{THD}_{\text {I }}$ terbesar terdapat di SDP 5 sebesar 34,80\%,SDP 6 sebesar 25,67\%, SDP 7 sebesar 12,04 \%. Masalah ini dikarenakan beban-beban non linier yang terpasang pada SDP 5, dan beban-beban setiap phasa di SDP 5 yang tidak berimbang.

\section{Analisis $T H D_{V}$ di PT.Wisesa Group}

Batas maksimum $\mathrm{THD}_{\mathrm{V}}$ di PT.Wisesa Group menurutt IEEEstandar 519-1992 adalah 5,0 \% karena tegangan dibawah $69 \mathrm{KV}$

Hasil Simulasi mengeluarkan nilai SDP 1 dengan nilai 2,46\%,SDP 2 dengan nilai 2,46\%,SDP 3 dengan nilai 2,46\%, SDP 4 dengan nilai $2,46 \%$ dan SDP 5 dengan Nilai $2,46 \%$,SDP 6 dengan nilai 2,46\%,SDP 7 dengan nilai 2,46\% Berikut ini merupakanhasil running simulasi $\mathrm{THD}_{\mathrm{V}}$ sesuai dengan tabel VI di bawah.

TABLE VI

PERBANDINGAN THD ${ }_{\mathrm{V}}$ DENGAN HASIL $R U N N I N G$ MENGUNAKAN SIMULASI DENGAN STANDART IEEE 519-1992

\begin{tabular}{|c|c|c|c|}
\hline Tempat & $\begin{array}{c}\text { Hasil running } \\
\operatorname{THD}_{\mathrm{V}}(\%) \\
\text { PT.Wisesa Group }\end{array}$ & $\begin{array}{c}\text { IEEE Standar } \\
519-1992 \\
\text { THD }_{\text {Vmax }}(\%)\end{array}$ & KET \\
\hline \multicolumn{4}{|c|}{ Gedung I } \\
\hline SDP 1 & 2,46 & 5.0 & Memenuhi Standar \\
\hline SDP 2 & 2,46 & 5.0 & Memenuhi Standar \\
\hline SDP 3 & 2,46 & 5.0 & Memenuhi Standar \\
\hline SDP 4 & 2,46 & 5.0 & Memenuhi Standar \\
\hline \multicolumn{4}{|c|}{ Gedung II } \\
\hline SDP 5 & 2,46 & 5.0 & Memenuhi Standar \\
\hline SDP 6 & 2,46 & 5.0 & Memenuhi Standar \\
\hline \multicolumn{4}{|l|}{ Gudang } \\
\hline SDP 7 & 2,46 & 5.0 & Memenuhi Standar \\
\hline
\end{tabular}

3. Running Spectrum Harmonik

Di bawah ini hasil running Spektrum harmonisa dan bentuk gelombang dari semulasi, $\mathrm{THD}_{\mathrm{v}}$ dan $\mathrm{THD}_{\mathrm{i}}$, seperti gambar 5 dan gambar 6 dibawah ini:
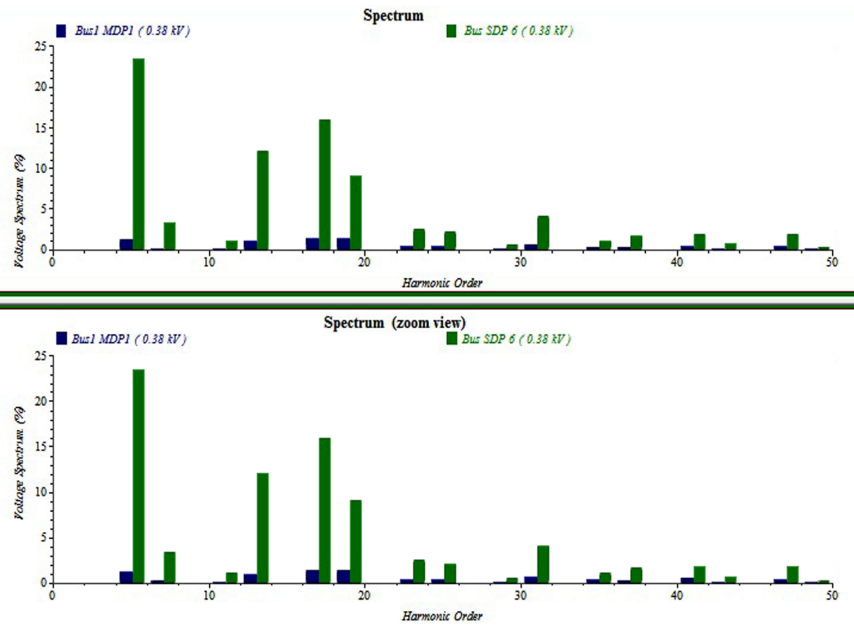

Gambar 5. Spektrum harmonic
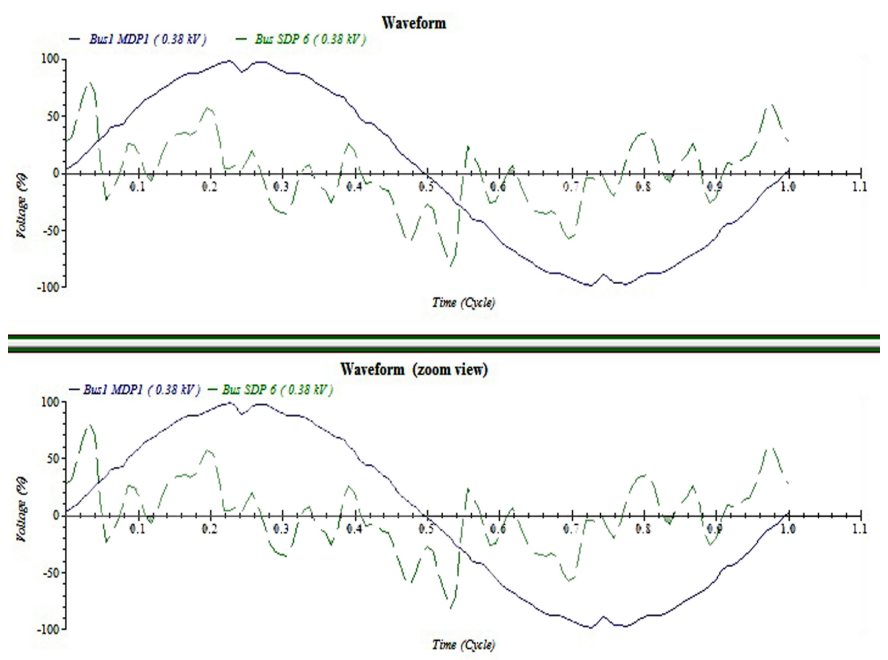

Gambar 6. Bentuk gelombang

Gambar 5 dan gambar 6 menunjukkan saat jaringan distorsi terdapat beban non linier dan bentuk gelombang sinusoidal mengalami cacat gelombang atau terdistorsi. Spektrum harmonic dan gelombang di simulasikan di SDP yang terdapat kandungan harmonisa tinggi yaitu di SDP 5.

\section{F. Analisis $T_{H} D_{I}$ pada Setiap SDP dengan Menggunakan Filter Pasif}

Untuk meredam distosri harmonisa dalam sistem tenaga, maka perlu mengunakan filter harmonisa yaitu filter pasif. Filter pasif terdiri dari induktor, kapasitor, resistor (R,L,C) dan unsur-unsur tahanan untuk meredam marmonisa. Teknik filter pasif yang menggunakan double tuned filter atau Type-C filter yang memiliki impedansi yang rendah untuk arus harmonisa pada frekuensi tertentu atau frekuensi tinggi atau band-pass filters (damped filters) dapat memfilter harmonisa di atas frekuensi tertentu (frequency bandwidth).

\section{Analisis Penempatan Filter Pasif Type $C$}


Penempatan filter pasif pada permodelan sintem klistrikan di PT.Wisesa Group yang di simulasikan di SDP 5 terlihat pada gambar 7.

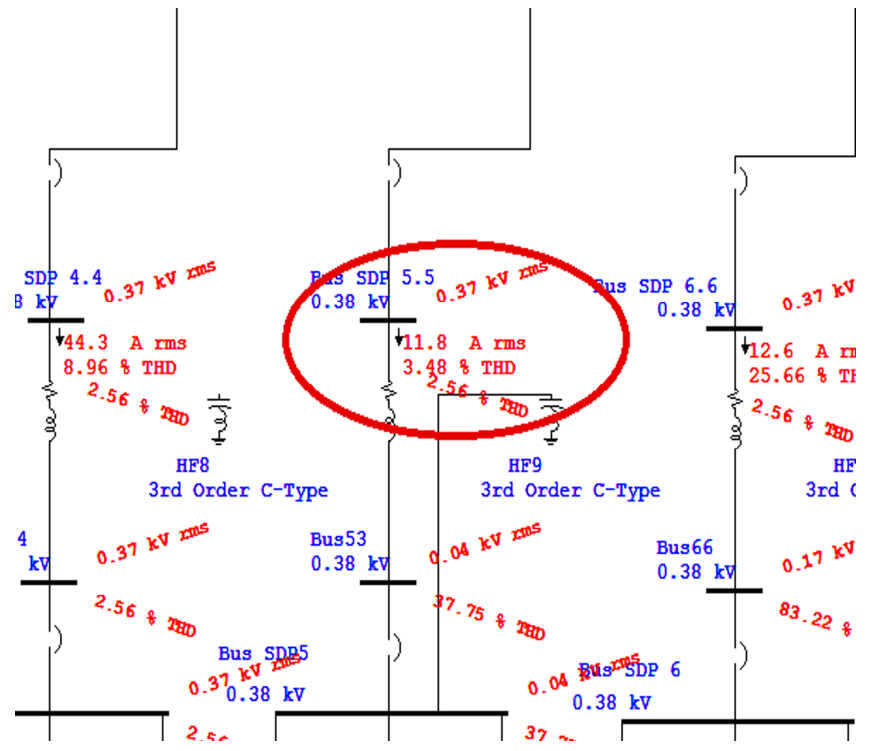

Gambar 7.Hasil Running Penempatan Filter Pasif di SDP 5

Dapat dilihat penambahan filter pasif pada SDP 5 dapat meurunkan $\mathrm{THD}_{\mathrm{I}}$ sebesar $31,32 \%$, yang sebelum di tanbahkan filter sebesar $34,80 \%$ dan setelah ditambahkan filter menjadi sesuai standar yaitu 3,48 \% dimana standar $\mathrm{THD}_{\mathrm{I}}$ di PT.Wisesa Group sebesar 5,0 \%.

\section{Analisis $T H D_{i}$ di PT.Wisesa Group Setelah di Pasang \\ Filter Pasif}

Hasil analisis $\mathrm{THD}_{\mathrm{i}}$ sebelum dan setelah penggunaan filter pasif type c serta perbandingannya dengan Standar IEEE 1521992 selengkapnya terlihat pada table VII.

TABEL VII

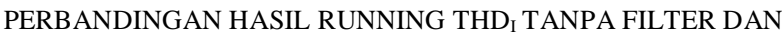
SESUDAH TERPASANG FILTER

\begin{tabular}{|c|c|c|c|c|}
\hline Tempat & $\begin{array}{c}\text { Hasil } \\
\text { running } \\
\text { THD } \\
\text { Tanpa } \\
\text { Filter }\end{array}$ & $\begin{array}{c}\text { Hasil running } \\
\text { THD }(\%) \\
\text { Terpasang } \\
\text { Filter }\end{array}$ & $\begin{array}{c}\text { IEEE } \\
\text { Standar 519 } \\
-1992 \\
\text { THD }_{\text {I }}(\%)\end{array}$ & KET \\
\hline \multicolumn{5}{|c|}{ Gedung I } \\
\hline SDP 1 & 8,98 & 3,22 & 5.0 & Standar \\
\hline SDP 2 & 8,98 & 3,83 & 5.0 & Standar \\
\hline SDP 3 & 8,97 & 2,41 & 5.0 & Standar \\
\hline SDP 4 & 8,97 & 3,40 & 5.0 & Standar \\
\hline \multicolumn{5}{|c|}{ Gedung II } \\
\hline SDP 5 & 34,80 & 3,48 & 5.0 & Standar \\
\hline SDP 6 & 25,67 & 3,30 & 5.0 & Standar \\
\hline \multicolumn{7}{|c|}{ Gudang } \\
\hline SDP 7 & 12,04 & 1,59 & 5.0 & Standar \\
\hline
\end{tabular}

3. Analisis $T H D_{v}$ di PT.Wisesa Group Setelah di Pasang Filter Pasif

I Wayan Wahyu Adi Merta: Analisis Pemasangan Filter Pasif...
Hasil analisis $\mathrm{THD}_{\mathrm{v}}$ sebelum penggunaan filter dan setelah penggunaan filter serta perbandingannya dengan Standar IEEE 152-1992 selengkapnya terlihat pada table VIII.

TABEL VIII

PERBANDINGAN HASIL RUNNING THD V TANPA FILTER DAN SESUDAH TERPASANG FILTER

\begin{tabular}{|c|c|c|c|c|}
\hline \multirow{5}{*}{ Tempat } & $\begin{array}{c}\text { Hasil } \\
\text { running } \\
\text { THD }_{\mathrm{v}}(\%) \\
\text { Tidak } \\
\text { Filter }\end{array}$ & $\begin{array}{c}\text { Hasil running } \\
\text { THD }_{\mathrm{v}}(\%) \\
\text { Terpasang } \\
\text { Filter }\end{array}$ & $\begin{array}{c}\text { IEEE } \\
\text { Standar 519 } \\
-1992 \\
\text { THD }_{\mathrm{v}}(\%)\end{array}$ & KET \\
\hline Gedung I \\
\hline SDP 1 & 2,46 & 2,33 & 5.0 & Standar \\
\hline SDP 2 & 2,46 & 2,33 & 5.0 & Standar \\
\hline SDP 3 & 2,46 & 2,33 & 5.0 & Standar \\
\hline SDP 4 & 2,46 & 2,35 & 5.0 & Standar \\
\hline \multicolumn{5}{|c|}{ Gedung II } \\
\hline SDP 5 & 2,46 & 2,56 & 5.0 & Standar \\
\hline SDP 6 & 2,46 & 2,50 & 5.0 & Standar \\
\hline \multicolumn{5}{|c|}{ Gudang } \\
\hline SDP 7 & 2,46 & 2,46 & 5.0 & Standar \\
\hline
\end{tabular}

\section{KESIMPULAN}

Berdasarkan hasil analisis pemasangan filter pasif untuk menanggulangi distorsi harmonisa terhadap beban non linie di PT.Wisesa Group, maka simpulan yang didapatkan adalah sebagai berikut:

1. Kandungan $\mathrm{THD}_{\mathrm{i}}$ di PT.Wisesa Group sebelum menggunakan filter pasif SDP1 sebesar 8,98\%, SDP2 sebesar 8,98\%, SDP3 sebesar 8,97\%, SDP4 sebesar $8,97 \%$, SDP5 sebesar $34,80 \%$, SDP6 $25,67 \%$, SDP7 sebesar $12,04 \%$ yang berarti tidak sesuai standar IEEE 519-1992 yang telah ditentukan yaitu sebesar $\leq 5 \%$. Untuk nilai $\mathrm{THD}_{\mathrm{v}}$ di PT.Wisesa Group sebesar 2,46\% dimana kondisi tersebut masih memenuhi standar maksimum $\mathrm{THD}_{\mathrm{v}}$ IEEE 519-1992 sebesar $\leq 5 \%$.

2. Kandungan $\mathrm{THD}_{\mathrm{i}}$ di PT.Wisesa Group setelah pemasangan filter pasif memenuhi Standar IEEE 5191992 yang telah ditentukan yaitu sebesar $\leq 5 \%$.

3. Penempatan filter pasif yang terbaik untuk menanggulangi distorsi pada simulasi terjadi di SDP 5, karena dapat menurunkan $\mathrm{THD}_{\mathrm{i}}$ terbesar yaitu sebesar $31,32 \%$ menjadi $3,48 \%$.

\section{REFERENSI}

[1] IEEE Std 519-1992, pp. 1-112. Apr. 1993 . IEEE Recommended Practices and Requirements for Harmonic Control in Electrical Power System.

[2] Waking Antonius Ibi, Rinas I Wayan, Suwardana.2013. Simulasi Penentuan Penempatan Filter Aktif Shunt Untuk Mendapatkan Distorsi Daya Yang terkecil di Blue Point Bay Villa \& SPA. Jimbaran: Majalah Ilmiah Teknik Elektro Universitas Udayana Vol 12.

[3] R. C. Dugan, M. F. McGranaghan, S. Santoso, and H. W. Beaty. 2012. Electrical Power Systems Quality, Third Edition. McGraw Hill Professional,

p-ISSN:1693 - 2951; e-ISSN: 2503-2372

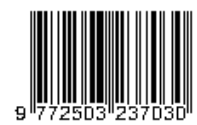


[4] Susiono. juni 2006. Penentuan Lokasi Filter Harmonik Optimum Pada Sistem Distribusi Daya listrik. Jimbaran : Majalah Ilmiah Teknik Elektro Universitas Udayana Vol 5.

[5] Sunanda Wahri, Yuli Asmi Rahma. Maret 2012. Aplikasi Filter Pasif Sebagai Pereduksi Harmonik Pada Inverter Tiga Fase. Jurnal Ilmiah Foristek Vol 1.

[6] Alexander, Suryajaya. 2011. Pengaruh Total Harmonic Distortion (THD) Pada Suatu Sistem. Semarang: Teknik Elektro Jurusan Teknologi Industri Universitas Katolik Soegijapranata.

[7] Samman Faizal Arya, Ahmad Rizkiyanti, Mustafa Mutiah. 2015 Perancangan Simulasi dan Analisis Harmonisa rangkian Inverter Satu Fasa. Makasar: Fakultas Teknik, Jurusan Teknik Elektro. Universitas Hasanuddin, 